\title{
BUDDHISM IN CHINA
}

A HISTORICAL SURVEY 



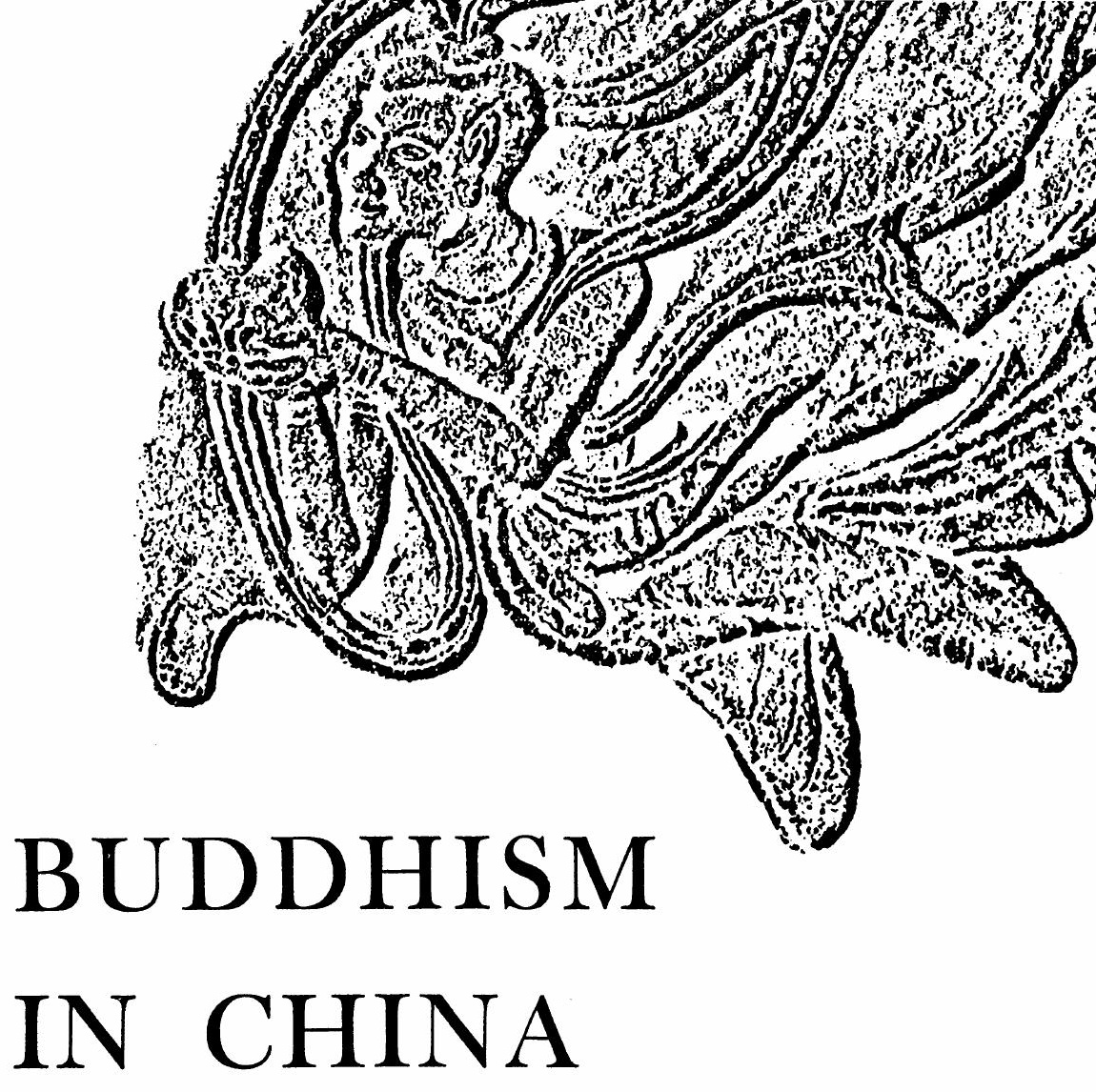

A HISTORICAL SURVEY

BY KENNETH K. S. CH'EN

PRINGETON UNIVERSITY PRESS

PRINCETON, NEW JERSEY 
Copyright @ 1964 by Princeton University Press A L L R I G H T S RESER V E D

L. C. Card: 63-23402

ISBN 0-691-00015-8 (paperback edn.) ISBN 0-691-03005-7 (hardcover edn.)

Printed in the United States of America

First Princeton Paperback Edition, 1972 Second Printing, 1973

$\begin{array}{lllllll}10 & 11 & 12 & 13 & 14 & 15 & 16\end{array}$

Princeton University Press books are printed on acid-free paper and meet the guidelines for permanence and durability of the Committee on Production Guidelines for Book Longevity of the Council on Library Resources 


\section{To the Memory of my Guru, Professor Walter Eugene Clark, who is now in nirvana}





\section{THE VIRGINIA AND RICHARD STEWART}

\section{MEMORIAL LECTURES}

Professor Ch'en's study of the history of Buddhism in China is the first fruit of a generous bequest by Miss Marie Stewart to the Council of the Humanities of Princeton University to establish a series of lectures and seminars in honor of her mother and father. The Virginia and Richard Stewart Memorial Lectures are designed to bring leading scholars of the religions of the world to the Princeton campus for a period of research, during which time, through public lectures and seminar discussions, they share with students and faculty the results of their studies.

This volume, the first in a series to be known as the "Princeton Studies in the History of Religions," is an attempt to share with an even wider audience knowledge of contemporary research into the history, beliefs, and practices of the varied religions of the world. It was Miss Stewart's hope that "these lectures will be made available for the widest possible public dissemination by every means in order that their influence upon all people may be more effective and enduring."

Philip H. Ashby

Department of Religion

Princeton University 
